National University of Life and Environmental Sciences of Ukraine

Kiev

National Academy of Agricultural Sciences

Kharkov

LESIA SOKOL

OLEKSANDR ZHEMOYDA

National University of Life and Environmental Sciences of Ukraine

Kiev

\title{
PROBLEMS OF RURAL SUSTAINABLE DEVELOPMENT IN UKRAINE
}

\begin{abstract}
For more than 30 years the world has been focusing on the idea of economy and ecology balance in terms of the need for its own social development. Such scientific approaches are called sustainable development. According to the 1987 Bruntland Report "sustainable development is development that meets the needs of the present without compromising the ability of future generations to meet their own needs".

In agriculture, we speak about a sustainable development as the balance of three aspects, namely economic, ecological and social. The main purpose of the article is to analyse the economic, ecological and social conditions of agricultural development. The analysis of official statistical data (State Statistics Service of Ukraine), research materials of Ukrainian and foreign scientists and own research results of the authors shows that Ukrainian agricultural policy pays much attention to the productive function, but it does not pay enough attention to the problem of social development, which underlays the experience of the state management of agriculture of Ukraine. These conclusions are based on the analysis of the macroeconomic indicators of the agriculture, the Ukrainian legislative base and the scientific proposals of the authors.
\end{abstract}

Keywords: sustainable development, development of rural areas, functions of agriculture, economic aspect, social aspect, ecological aspect.

JEL codes: Q01, Q56, Q57. 


\section{Introduction}

One of the most important goals of Ukrainian science is to state the purpose of tendencies which provide a complex systematic approach to forming a state agrarian policy based on sustainable development principles for economic growth, social development and, at the same time, creating safe conditions for living in rural areas as well as restoring the natural environment.

The United Nations Commission on Sustainable Development defined the goal for sustainable development (SD) as satisfaction of the needs of the modern post-industrial society without endangering the ability of future generations to satisfy their needs. The theory of sustainable development is an alternative to the paradigm of industrial and economic growth, which ignores the ecological danger when the society develops according to the extensive model.

The decision to continue the expansion of sustainable development and to work out and implement appropriate strategic documents was made at the summits held in Rio de Janeiro (Brazil in 1992), Johannesburg (RSA in 2002) and Copenhagen (Denmark in 2010), as well as at Conferences of Ministers of Environmental Protection of Europe. For countries of the Central Europe, Caucasus and Central Asia of great value is the framework document, which was approved at the fifth Kyiv Pan-European Conference of Ministers of Environment (2003). This document is entitled "Ecological partnerships in the region of EEC of UNO: ecological strategy for the countries of Eastern Europe, Caucasus and Central Asia (EECCA)". This document formed the foundation for outlining the Strategy of sustainable development policy for countries of EECCA.

The world experience identifies more than twelve functions of agriculture. We believe that the most significant ones are productive, social, ecological, infrastructural and historical, and cultural functions. The first three, i.e. productive and technological, social and demographic, ecological and recreational functions, form and enhance the sustainability of rural development.

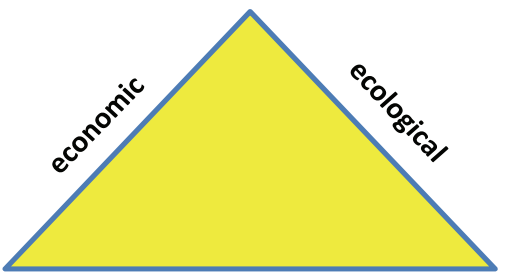

social

Sustainable Development

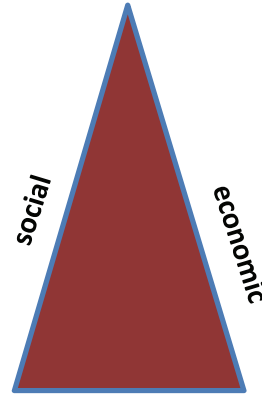

ecological

G-20

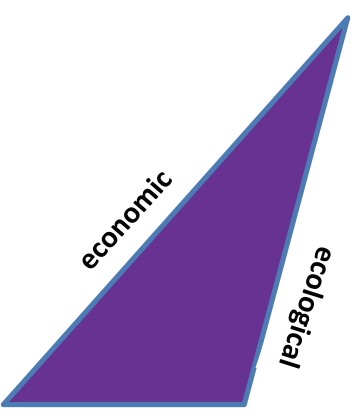

social

Ukraine

Fig. 1. Types of sustainability of agricultural economics.

Source: Kvasha (2013). 
Ukraine has begun to change the sustainability theoretically and legally, but the of sustainable development priorities have not yet been implemented in practice. The objectives of this article are to study the current problems of the economic, social and ecological development of agriculture, and the development of practical recommendations for the achievement of sustainability.

Following the previous researches by Kvasha (2013), there are three types of sustainability of agricultural economics according to functions of agriculture, RIO+20 (Fig. 1).

\section{Materials and methods}

Analysis of social, economic and ecological development of Ukraine was based on the data of the State Statistic Service of Ukraine. The theoretical base for research was prepared by Ukrainian and foreign economists. In the description of approaches, the authors used the sustainable concepts, developed for the EU countries under the Europe 2020 Strategy. However, Ukraine has not joined the process of implementation of "Agenda 2000", which was approved at the World Summit supported by UNO in Rio de Janeiro in 1992. The Concept and the Strategy of Ukraine's shift to sustainable development has not been adopted, but if it had been adopted they could establish the legal basis for relevant domestic reforms in the economy and social life. Because these basic strategic documents are lacking, the Cabinet of Ministries of Ukraine does not focus its actions on the structural and technological modernization of the country according to the principles of sustainable development. The research period covered data for 2003-2016.

\section{Results and discussion}

Theoretically, the Ukrainian National Concept of sustainable development become a part of the international global concept, which necessarily includes all organizational society levels: national, regional, local. This process is reflected in the conceptual model for sustainable development implementation (Sokol, 2013) (Fig. 2).

In 2007, the Cabinet of Ministers of Ukraine approved the Concept of National Environmental Policy of Ukraine by 2020. The purpose of the document is to stabilize and improve the ecological state of Ukraine by means of establishing national ecological policy as a factor of the integrated socio-economic development of the country, to ensure transition to sustainable development and implementation of ecologically balanced system of natural resources use. But the document has imperfect tools and objectives of rationalizing land use and was not reviewed since its entry into force.

Unfortunately, the Strategy of agricultural sector development for the period up to 2020 (2013) and the Concept of the State programme of agricultural sector development for the period up to 2020, do not take into account the priorities of socio-ecological-economic development of agriculture. 


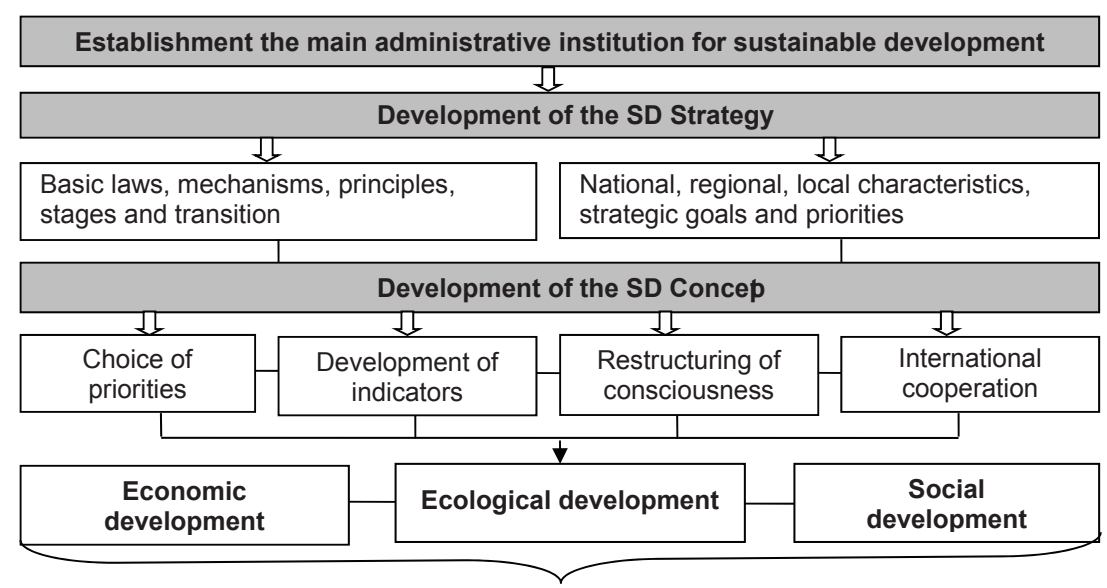

SUSTAINABLE DEVELOPMENT

Fig. 2. Conceptual model of sustainable development implementation.

Source: own concept of the authors of the article.

According to the opinion of the article's authors Ukraine is becoming a civil society. In this case, we need to emphasize the necessity to focus on providing and supporting socially oriented sustainable development, where a social factor is a dominant one in forming a renewed rural environment. In this context, an ecological and economic constituent must be considered to be the instrument of achieving the set goals. In recent years, our science has been paying attention to the category "rural area" and "sustainable rural development". It means that we consider the problems of rural population, their labour and life from the point of view of social welfare and territorial development.

The Institute for Applied Systems Analysis of the National Academy of Ukraine (iasa.kpi.ua) has succeeded in developing a system of indicators of sustainable development, which consists of indicators of economic (Ukraine takes the $91^{\text {st }}$ place among 117 countries), social (the $72^{\text {nd }}$ ), and ecological (the $108^{\text {th }}$ ) dimensions, and offered the system for use. Each of these indicators is measured using indices and criteria well-known in the global practice. However, the current reasoning about the nature of men's territorial activity, which is based on economic and social priorities remains second-rate.

Development of indicative system of sustainable development is reflected in the research of Nobel Prize winners in Economics - Joseph Stiglitz and Amartya Sen. They recognized that GDP does not reflect the real conditions of life and they called for development of other instruments to assess welfare of nations. Therefore, some states in order to assess progress use such indicators as Gross National Happiness (Reytynh nayshchaslyvishykh krayin, 2017). In 2006, an important indicator of sustainable development was offered by New Econom- 
ics Foundation for analysis of people's welfare and state of the environment in different countries - Happy Planet Index. There are three indicators for calculating this index: subjective life satisfaction of people, life expectancy and the so-called ecological footprint. The one of the most spectacular examples for description of the measure of social welfare is the index of happiness, presented and published by the United Nations Sustainable Development Solutions Network. In the overall ranking of happiness, covering the years between 2014 and 2016, Ukraine was ranked $132^{\text {nd }}$ among 155 countries (Fig. 3).

Ukraine has concentrated its attention on the problems of agricultural production and employment, income increase and welfare of rural population. Certainly, this approach is justified and necessary, but in our opinion, it only partially solves the problems of rural areas. Today, the agricultural producer leaves the problem of social development of rural territories aside.

Thus, the authors of the article concluded that large agricultural farms, which are often registered and pay taxes not at the place of conducting their production activities, leave their local budgets almost without income which could have been used for various social programmes and activities. The current tax load on agricultural producers, specifically the Single Farm Tax, is also a limiting budget-forming factor, as annual income of local budgets was only 126-150 million hryvnia in 2015. The low level of farmers' salary does not allow them to pay for the services offered by business entities, such as cultural, educational, medical, transport, etc.; tax allocation from individuals, who produce agricultural products, was approximately 1.4 billion hryvnias annually in the last 3 years.

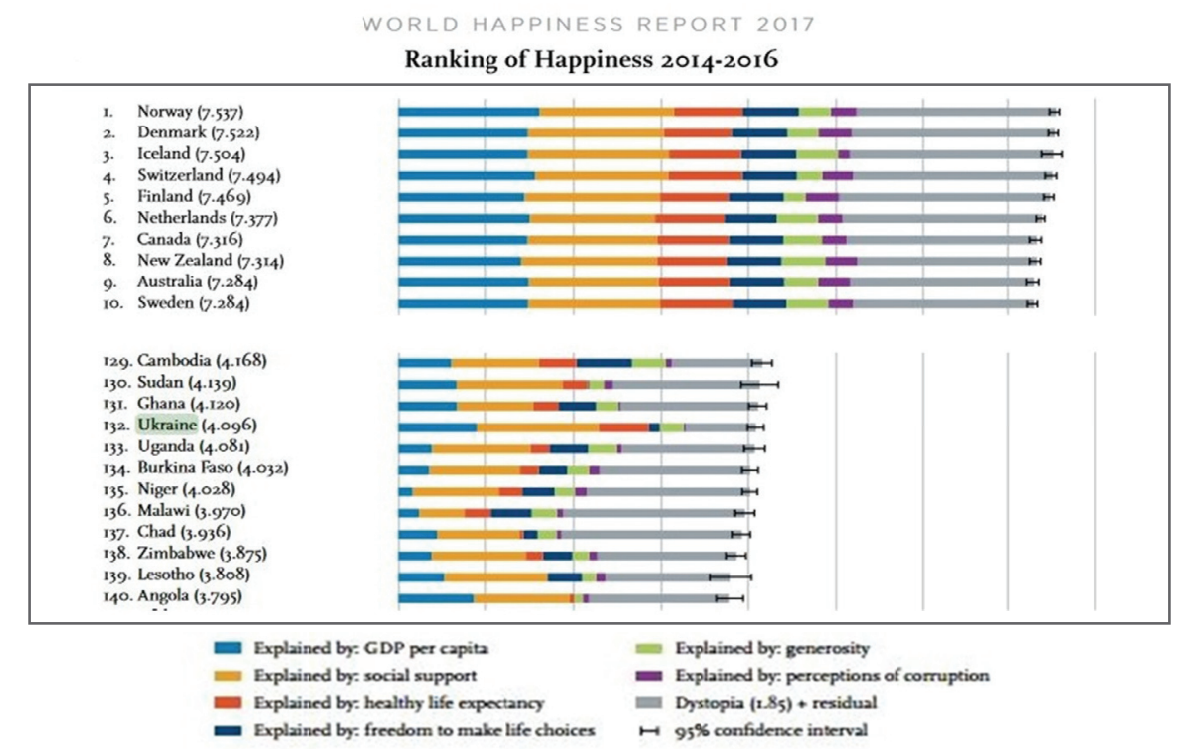

Fig. 3. World happiness index and place of Ukraine in the ranking, 2014-2016.

Source: Reytynh nayshchaslyvishykh krayin (2017). 
The scarce money from local budgets, which was given to support sustainable development in rural areas in 2009, was less than 1 billion hryvnia and, in fact, it did not affect territorial forming in rural areas. State target programme for the development of rural areas in Ukraine by 2015 predicted 2.2 billion hryvnia for the purpose. At present, the situation in rural areas is: "the producer does not want - the community is not able to act", and it is being manifested in uncooperative behaviour. The local budget is insufficient, and the state does not oblige or encourage producers to implement sustainable development priorities.

Authors must note that this process is progressing very rapidly. Policy decision lacks regional specificities and integrity, and without these only local and short-term effects of some support activities are possible. We strongly need significant financial resources to stop degradation processes and to support social domain of rural areas and rural population. Researchers from the ESC Institute of agrarian economy have calculated that annually this amount must not be less than 23 billion hryvnia. These calculations are to be approved on the basis of the Concept of Strategy of the agricultural development of Ukraine by 2020 . Because of deflationary financial and economic situation, and the lack of the state support in the social domain, it is almost impossible to shift to the model of efficient satisfaction of the interests of the rural population.

According to official statistical data and USDA indexes, the Ukrainian agriculture accounts for $13-15 \%$ of the total GDP and up to $10 \%$ of income to the budget of the country, and up to $17 \%$ of export potential of the country. The export of Ukraine constitutes approximately 1.6-1.8\% of world grain volume, 20-21\% of sunflower seeds. In 2013-2014, Ukraine's share in world grain trade was $9 \%$, including barley $-30 \%$, wheat $-8 \%$, maize $-9 \%$. More than $43 \%$ of world sunflower oil export belongs to Ukrainian oil.

The share of agricultural exports in total exports of the country in 2017 amounted to $42 \%$ (Fig. 4). The share in total exportis: grain $-41.4 \%$, oil $-26.8 \%$, oilseeds $-10.1 \%$.
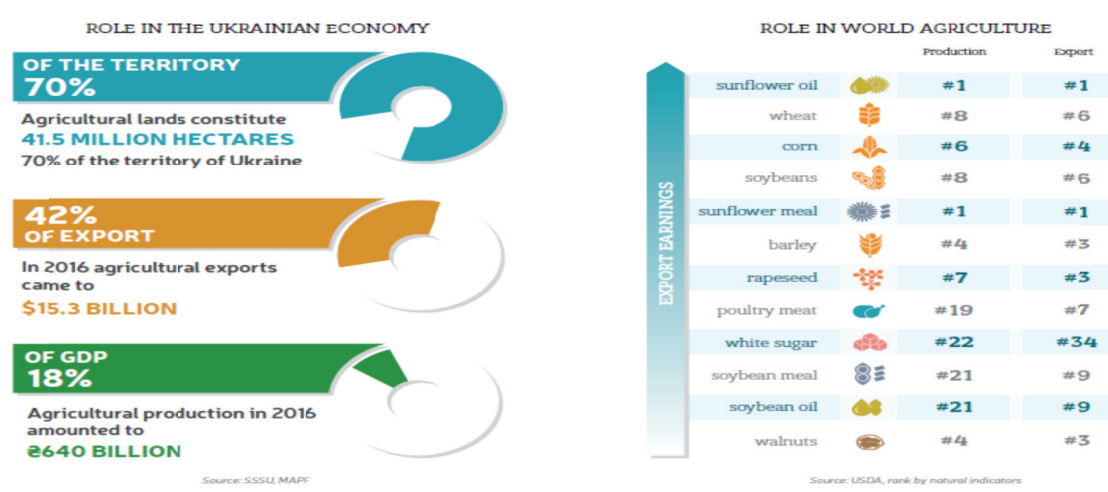

Fig. 4. Ukrainian agri-food trade, 2015-2016.

Source: Statistics Service of Ukraine, USDA. 
Domestic agriculture and industrial complex almost completely satisfy the internal market demand for the main agricultural products and primary materials. There are some changeable trends in respective years as regards satisfying the meat demand, and in 2015 in sugar demand. In the financial crisis, agriculture and industrial complex became one of the budget revenues for the economy of the country (Fig. 5).

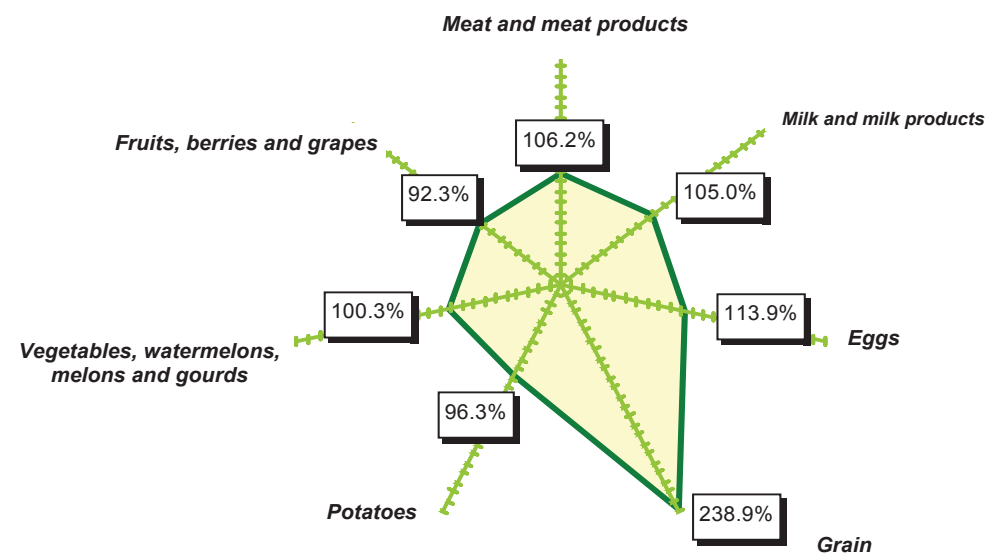

Fig. 5. The level of self-sufficiency for main food products of the population of Ukraine in 2015 (\%, production to internal consumption in Ukraine).

Source: State Statistics Service of Ukraine.

In 2014, the income to Consolidated budget from agriculture amounted to more than 45 billion hryvnia, of which approximately 130 billion hryvnia was a fixed agricultural tax. The analysis shows that the agricultural production in Ukraine is characterized by positive tendencies which, apart from global price growths, mostly depend on the state support to the sector. The total amount of taxes paid by the agricultural sector amounted in 2004 to $1.2 ; 2013-7.8 ; 2014-8.7$; 2015 - 14.4 billion hryvnia.

The social domain of rural areas has been characterized by the opposite vector of the development for the whole period of Ukraine's independence. Since 1990s, the social infrastructure of rural development has been deteriorating in Ukraine, mortality prevails birth, and consequently entire villages disappear which is proved statistically. On January 1, 1990 there were 28,804 villages in Ukraine where lived 16,969,300 people, on January 1, 2008 there were only 28,504 where there lived 14,631,000 people. The isolation of the working age population from productive work on land and the increase in intensification in agriculture have resulted in disappearance of 300 villages for the last eighteen years and rural areas have depopulated by $2,337,528$ people. Rural population is decreasing four times quicker than urban one -10.1 people per 1,000 people 
(earlier it was 2.5 per 1,000 people). According to the criteria of potential demography, the probable maximum limit of retaining Ukrainian rural area is three generations (Fig. 6).

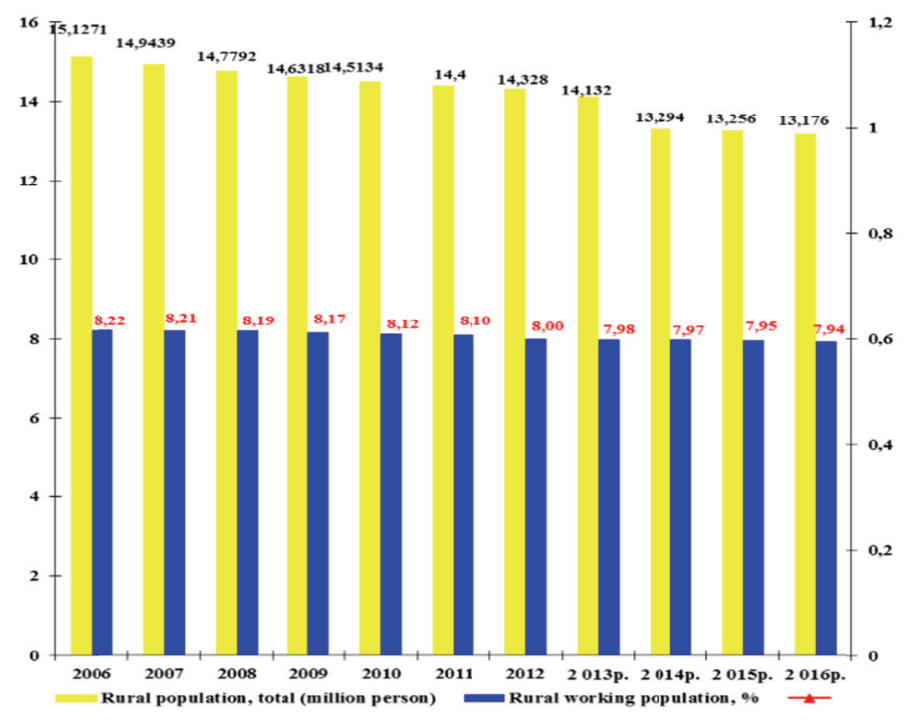

Fig. 6. Total rural population in Ukraine (2016, million persons).

Source: State Statistics Service of Ukraine.

According to official statistical data and research results the level of the average wage in agriculture is growing, and employment in agriculture is declining rapidly (Fig. 7). In addition, $47.5 \%$ of villages do not have medical stations mandatory for each village; $31.4 \%$ of villages are provided with child care centres (garden), schools $-46.6 \%$, cultural establishments $-57.9 \%$. The public services are absent almost completely.

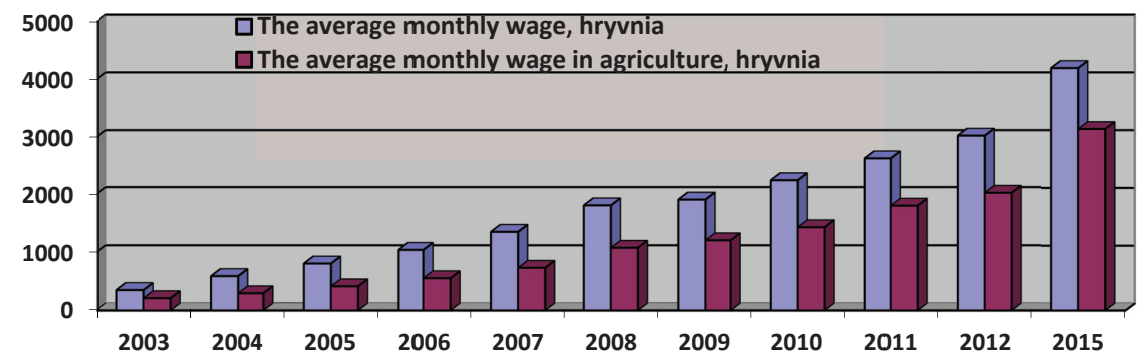

Fig. 7. The average monthly wage in Ukraine, hryvnia.

Source: State Statistics Service of Ukraine. 
An important constituent of rural sustainable development is ecological domain. It includes two issues. The first is the capability of agricultural production without causing ecological damage, and the second is the ecological problem of rural areas in terms of their physical, chemical and biological contamination. Vertical level of organic agricultural production that is the chain "from the land to the table" consists of the following components: ecological assessment of the land, plant, technology, agricultural product and the product of its processing. The authors' analysis of the ecological condition of the environment, its restoration and assimilatory resources, the purity of the most important natural resources, every one of which defines a healthy physical and mental development of a person, and the efficiency of agricultural production, etc., shows that for the last 30 years the area of eroded land increased almost 1.5 times, the area of saline, oxidized, waterlogged and technologically contaminated farmland has expanded significantly. In total, in 2015 only one per 10 ha is in a good ecological condition.

The popular indicator of sustainable development is Green GDP (Environmentally-Adjusted Domestic Product, Eco-Domestic Product), taking into account the environmental factor. The general approach to determining the economic essence of this indicator is in the social product adjustment, based on changes in environmental assets, resources and wealth: Green GDP $=$ GDP economic losses from environmental pollution. Economic losses from environmental pollution can be considered as the sum of environmental taxes as environmental protection costs. Environmental payments will include energy taxes, pollution charges, waste placement fees, transport taxes, emissions tax, etc.

Figure 8 describes the dynamics of sustainable development indicators of Ukraine, taking into account the environmental component of GDP in Ukraine during 2007-2012 (Sustainable Development Goals).

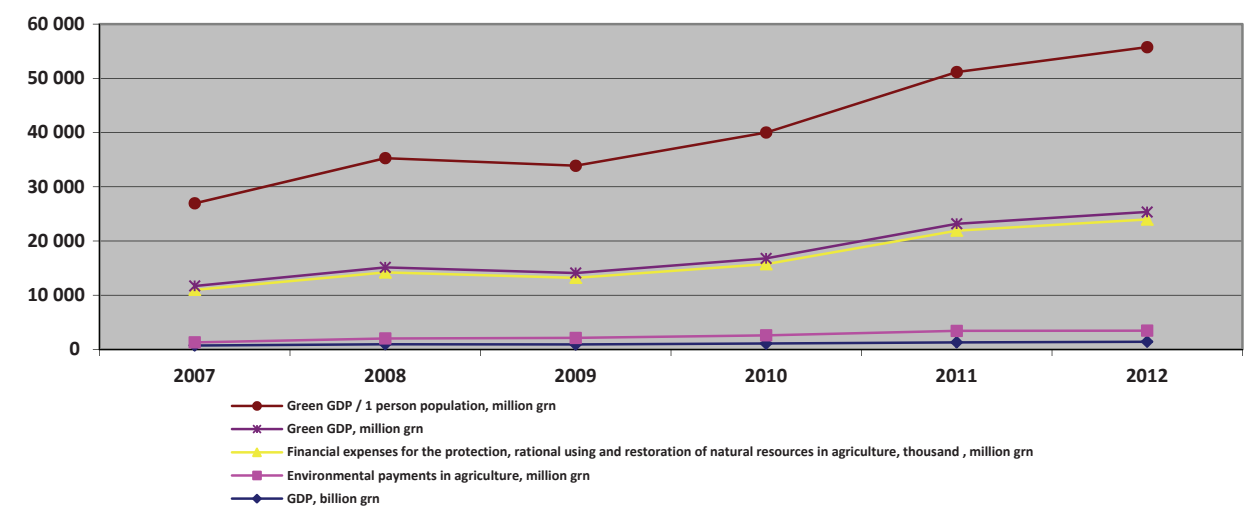

Fig. 8. The dynamics of environmental indicators of Ukraine.

Source: State Statistics Service of Ukraine. 
The analysis shows the growth in the gross domestic product over the past 6 years. Along with the indicator, Green GDP growth also nearly doubled. Negative effect is the increase of economic losses from environmental pollution in agricultural production.

Often the water and agricultural products of rural areas do not meet the quality requirements as a result of an uncontrolled use of organic and mineral fertilizers and plant protection products, domestic animals and poultry over-crowdedness, failure to comply with sanitary and hygienic requirements resulting in the failure of the ecological control of rural areas, the lack of knowledge about ecological problems of the environment. There also exists a risk of contaminating the land with pathogenic microorganisms and helminths that together with chemical contaminators increases the negative impact on the health of rural population (Peresichnyi and Fedorova, 2013).

This also relates to 2030 Agenda, offered by UN in 2015 (Sustainable Development Goals (SDGs) of the 2030 Agenda for Sustainable Development). For sustainable development for Ukrainian agriculture and rural areas it means that our country is now related to the World Best Practices.

In other words, the problem of balanced development of agriculture using technologies which increase production productivity, at the same time, being environment-friendly is becoming burning. In these conditions a social factor becomes dominant in agricultural production.

\section{Conclusions}

Based on our research, to measure the strategic goals for solving the general aspects of the problem we can propose the following:

- to base the Ukrainian National programme of demographic development for rural areas on the approaches of the European and G-20 strategies preconditions revival of rural areas, focusing on the effective land use to produce sufficient and ecological products by individual farms;

- to develop the local administration reform in order to create a single balanced system of rural areas development, to shift to self-governance of the local communities.

At the same time, to achieve the goals aimed at providing efficiency of agriculture:

- as far as tax legislation - indicated as one of the key factors for rural development, it is reasonable to improve it taking into consideration the resolution of issues of sustainable development of rural areas;

- it is also expedient to establish the state supporting fund for the development of rural areas, which can be based on the European best practices (using the relocation of the part of funds from a farm activities and incomes);

- additionally, the local rural development, green tourism and local production development should be based on principals of equal market access and cooperation. 
To solve ecological problems of sustainable development of rural areas, to develop and implement measures to save and restore soil fertility, it is necessary to develop a system of clear monitoring at the national, regional and local levels. This system can deliver the comprehensive monitoring of ecological, economic and social indicators of development. 


\section{References}

Abdallah, S., Thompson, S., Michaelson, J., Marks, N., Steuer, N. (2009). The Happy Planet Index 2.0. New Economics Foundation. Retrieved from: http://www.neweconomics.org/ gen/uploads/d144k145g5scuy453044gqbu11072006194758.pdf.

Kvasha, S.M. (2013). Methodological basis for decision making in agricultural policy. Ekonomika APK, no. 8, pp. 12-24.

Peresichnyi, M., Fedorova, D. (2013). The electroactivated water in human nutrition. Retrieved from: http://tr.knteu.kiev.ua/files/2013/15/9.pdf.

Pro skhvalennya Kontseptsiyi Derzhavnoyi tsilovoyi prohramy rozvytku ahrarnoho sektoru ekonomiky na period do 2020 roku. Rozporyadzhennya Kabinetu Ministriv Ukrayiny vid 30 hrudnya 2015 roku No. 1437-r. Retrieved from: http://www.kmu.gov.ua/control/ uk/cardnpd?docid=248907971.

Pro skhvalennya Kontseptsiyi natsionalnoyi ekolohichnoyi polityky Ukrayiny na period do 2020 roku. Rozporyadzhennya Kabinetu Ministriv Ukrayiny vid 17 zhovtnya 2007 roku No. 880-r. Retrieved from: http://zakon3.rada.gov.ua/laws/show/880-2007-\%D1\%80.

Pro skhvalennya Stratehiyi rozvytku ahrarnoho sektoru ekonomiky na period do 2020 roku. Rozporyadzhennya Kabinetu Ministriv Ukrayiny vid 17 zhovtnya 2013 roku No. 806-r. Retrieved from: http://zakon3.rada.gov.ua/laws/show/806-2013-\%D1\%80.

Reytynh nayshchaslyvishykh krayin: Riven shchastya ukrayintsiv znyzhuyetsya (2017). Retrieved from: http://ua.112.ua/suspilstvo/reitynh-naishchaslyvishykh-krain-rivenshchastia-ukraintsiv-znyzhuietsia-298538.html.

Shiva, V. (2013). How economic growth has become anti-life. The Guardian/UK. November 01, 2013. Retrieved from: http://www.theguardian.com/commentisfree/2013/ nov/01/how-economic-growth-has-become-anti-life.

Sokol, L.M. (2013). Kontseptualni osnovy staloho rozvytku silskohospodarskoho pryrodokorystuvannya. Visnyk NUBiP Ukrayiny: Seriya «Ekonomika, ahrarnyy menedzhment ta biznes». Vyp. 181, CH.2, pp. 299-306.

Sokol, L.M. (2016). Upravlinnya ekolohichnoyu skladovoyu silskohospodarskoho pryrodokorystuvannya v umovakh hlobalizatsiyi ekonomiky: Monohrafiya. Kiev: TSP «Komprynt», pp. 240. ISBN 978-966-929-330-5.

Sustainable Development Goals (SDGs) of the 2030 Agenda for Sustainable Development. Retrieved from: http://www.un.org/sustainabledevelopment/development-agenda/.

The State Statistics Service of Ukraine. Retrieved from: http://www.ukrstat.gov.ua.

United Nations Economic Commission for Europe (2003). Environmental Partnerships in the UN ECE Region: Environment Strategy for Countries of Eastern Europe, Caucasus and Central Asia. Strategic Framework. Fifth Ministerial Conference "Environment for Europe". Kiev, Ukraine, 21-23 May 2003. ECE/CEP/105/Rev.1.

United Nations World Commission on Environment and Development (1987). Our Common Future. Oxford: Oxford University Press.

Zhemoyda, O., Yanchevskyi, R. (2011). The evaluation of human capital for Ukrainian rural population. Naukowyj wisnyk Uniwersytetu Rolniczego w Kyjowie. Seria: Ekonomika, Zarzazanie Rolnictwa, business, No. 163, pp. 174-179. 
SERGII KVASHA

Narodowy Uniwersytet Przyrodniczy i Nauk o Środowisku Ukrainy

Kijów

Narodowa Akademia Nauk Rolniczych Ukrainy

Charków

SOKOL LESIA

OLEKSANDR ZHEMOYDA

Narodowy Uniwersytet Przyrodniczy i Nauk o Środowisku Ukrainy

Kijów

\title{
PROBLEMY ZRÓWNOWAŻONEGO ROZWOJU OBSZARÓW WIEJSKICH NA UKRAINIE
}

\begin{abstract}
Abstrakt
Od ponad 30 lat świat skupia się na koncepcji równowagi pomiędzy gospodarka a ekologia pod katem potrzeby własnego rozwoju społecznego. To naukowe podejście nosi miano zrównoważonego rozwoju. Według raportu Komisji Bruntlanda z 1987 r. „rozwój zrównoważony to rozwój, który spełnia potrzeby teraźniejsze, nie zakłócając możliwości przyszłych pokoleń zaspokojenia ich własnych potrzeb”.

W rolnictwie mówimy o zrównoważonym rozwoju jako równowadze trzech aspektów, a mianowicie ekonomicznego, ekologicznego i społecznego. Głównym celem artykułu jest analiza ekonomicznych, ekologicznych i społecznych warunków rozwoju rolnictwa. Analiza oficjalnych danych statystycznych (State Statistics Service of Ukraine), materiałów badawczych naukowców ukraińskich i zagranicznych oraz wyniki własnych badań autorów pokazują, że w polityce rolnej Ukrainy duża wage przywiazuje sie do funkcji produkcyjnych, ale $w$ niewystarczajacym stopniu podkreśla sie problem rozwoju społecznego, leżacy u podstaw doświadczenia w zarzadzaniu rolnictwem na Ukrainie. Wnioski te opieraja się na analizie wskaźników makroekonomicznych rolnictwa, podstawowym prawodawstwie Ukrainy i propozycjach naukowych autorów.
\end{abstract}

Słowa kluczowe: zrównoważony rozwój, rozwój obszarów wiejskich, funkcje rolnictwa, aspekt ekonomiczny, aspekt społeczny, aspekt ekologiczny.

Accepted for print: 07.12.2017.

Unless stated otherwise all the materials on the website are available under the Creative Commons Attribution 3.0 Poland license. Some rights reserved to the Institute of Agricultural and Food Economics - National Research Institute.

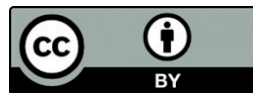

